\title{
Analisis Kesalahan Mahasiswa pada Mata Kuliah Kalkulus Peubah Banyak Berdasarkan Newmann's Error Analysis
}

\author{
Muhamad Farhan $^{1}$ \& Ihwan Zulkarnain ${ }^{2}$ \\ Universitas Indraprasta PGRI.
}

\begin{tabular}{l} 
INFO ARTICLES \\
\hline Article History: \\
Received: $31-M e i-2019$ \\
Revised: 08-Juni-2019 \\
Approved: 20-Juni-2019 \\
Publish Online: 26-Juni-2019
\end{tabular}

Key Words:

Task Commitment, Sikap Siswa pada Pelajaran Matematika, Kemampuan Pemahaman Konsep Matematika.

\begin{abstract}
This study aims to determine student errors in many variable calculus courses and the factors that cause these errors. This research is a qualitative research. The research subjects were students level 5 of the academic year 2018/2019 Mathematics Education Study Program, Indraprasta University PGRI Jakarta. Data collection techniques used are test, observation and documentation. The data analysis technique by analyzing qualitative, namely data reduction, presentation and conclusion. The results of the study indicate that the types of errors that often occur in the stages of reading, transformation and process skills, which include mistakes in understanding questions, errors in determining the right formula, conceptual errors (errors in algebraic and trigonometric derivatives, elimination and substitution processes and errors form manipulation algebraic gamma function). The factors that students to make mistakes are lack of understanding the problem, lack of understanding the concept of derivatives, integrals and elimination-substitution, not careful in the calculation process and lack of practice working on questions with varied forms.
\end{abstract}

\begin{abstract}
Abstrak: Penelitian ini bertujuan untuk mengetahui kesalahan mahasiswa pada matakuliah kalkulus peubah banyak dan faktor-faktor yang menyebabkan kesalahan tersebut. Penelitian ini merupakan penelitian kualitatif. Subjek penelitian adalah mahasiswa semester V tahun akademik 2018/2019 Program Studi Pendidikan Matematika, Universitas Indraprasta PGRI Jakarta. Teknik pengumpulan data yang digunakan yaitu tes, observasi dan dokumentasi. Teknik analisis data dilakukan dengan analisis data kualitatif, yaitu reduksi data, penyajian data dan penarikan kesimpulan. Hasil penelitian ini menunjukkan bahwa jenis kesalahan yang sering terjadi pada tahapan reading, transformasi dan process skill, yang meliputi kesalahan memahami soal, kesalahan menentukan formula yang tepat, kesalahan konsep (kesalahan menentukan turunan aljabar dan trigonometri, proses eliminasi dan substitusi serta kesalahan dalam manipulasi bentuk aljabar fungsi gamma). faktor-faktor yang menyebabkan mahasiswa melakukan kesalahan yaitu kurang memahami soal, kurang memahami konsep turunan, integral dan proses eliminasi-substitusi, kurang teliti dalam proses perhitungan dan kurang latihan mengerjakan soal-soal dengan bentuk yang bervariasi.
\end{abstract}

Correspondence Address: Jln. Raya Tengah No. 80 Kelurahan Gedong Pasar Rebo Jakarta Timur, Jakarta, Indonesia. e-mail: muhamadfarhan2011@gmail.com

How to Cite (APA $6^{\text {th }}$ Style): Farhan, M. \& Zulkarnain, I. (2019). Analisis Kesalahan Mahasiswa pada Mata Kuliah Kalkulus Peubah Banyak Berdasarkan Newmann's Error Analysis. JKPM (Jurnal Kajian Pendidikan Matematika), 4(2): 121-134.

Copyright: Farhan, M. \& Zulkarnain, I. (2019)

Competing Interests Disclosures: The authors declare that they have no significant competing financial, professional or personal interests that might have influenced the performance or presentation of the work described in this manuscript. 


\section{PENDAHULUAN}

Salah satu tujuan pembelajaran matematika adalah peserta didik mampu memahami konsep, menjelaskan keterkaitan antara konsep dan mampu memecahkan masalah matematis pada level kesulitan tertentu dengan baik dan benar. Pentingnya konsep matematika akan memberikan kemudahan peserta didik untuk memahami masalah, merancang strategi penyelesaian, dan menyelesaikan masalah secara terstruktur dan tersistematis. Membangun konsep matematis perlu adanya racangan proses pembelajaran yang baik, NCTM dalam Farhan \& Retnawati (2014) menekankan pada lima standar proses pembelajaran yaitu pemecahan masalah (problem solving), penalaran dan bukti (reason and proof), komunikasi (communication), koneksi (connections), dan representasi (representation). Lima standar proses pembelajaran ini akan membangun sikap matematis yang positif berupa rasa antusias yang tinggi terhadap matakuliah kalkulus, hal ini sejalan dengan pernyataan Hakim (2016) bahwa peserta didik dengan kualitas sikap yang baik biasanya memiliki opini positif pada matematika, suka dan antusias mengikuti seluruh rangkaian kegiatan belajar matematika, juga memiliki niat yang kuat untuk memahami substansi kajian matematika dengan sebaik-baiknya. Oleh karena itu, membangun sikap positif mahasiswa terhadap matakuliah kalkulus perlu ditekankan pada proses pembelajaran disebabkan keterkaitan antara konsep akan memudahkan mahasiswa dalam proses pemecahan masalah kalkulus peubah banyak.

Kalkulus peubah banyak merupakan matakuliah wajib mahasiswa semester 5 pada program studi pendidikan matematika universitas Indraprasta Jakarta sebagai kelanjutan dari matakuliah kalkulus differensial dan kalkulus integral. Ruang lingkup materi yang diajarkan adalah sistem koordinat, turunan fungsi dua peubah (turunan parsial), optimisasi menggunakan turunan fungsi dua peubah, metode lagrange, integral lipat dan aplikasinya, fungsi gamma, fungsi beta dan fungsi laplace. Standarisasi mahasiswa dapat memahami matakuliah kalkulus peubah banyak adalah mahasiswa mampu memahami dan menguasai konsep turunan dan integral. Mahasiswa yang sudah memahami dengan baik konsep turunan dan integral tentunya akan lebih mudah dalam mengkaji dan memahami serta mampu menyelesaikan masalah kalkulus peubah banyak dengan baik dan benar. Demikian sebaliknya, mahasiswa yang belum sepenuhnya memahami konsep turunan dan integral akan lebih besar kemungkinan untuk melakukan kesalahan-kesalahan terutama kesalahan konsep dan mahasiswa lebih cenderung gagal dalam memecahkan masalah kalkulus peubah banyak.

Berdasarkan hasil pretest di awal perkuliahan dengan memberikan soal turunan dan integral menunjukkan bahwa mahasiswa tidak mampu memberikan solusi matematis terhadap soal turunan dan integral yang diberikan dengan baik dan benar. Setelah dikonfirmasi berupa wawancara sebagian besar mahasiswa menyatakan bahwa matakuliah kalkulus terutama pada materi turunan dan integral merupakan materi tersulit dan sukar untuk dipahami. Anggapan seperti ini, menyebabkan mahasiswa semakin sulit untuk memahami dan menyelesaikan masalah turunan dan integral yg merupakan konsep dasar matakuliah kalkulus peubah banyak serta peluang mahasiswa melakukan kesalahan-kesalahan pada proses pemecahan masalah semakin lebih besar dan secara continue kesalahan-kesalahan ini akan terus berulang.

Menurut Clement (Mujib, 2017) tipe-tipe kesalahan sebagai berikut: (1) Coreless error, yaitu kesalahan karena kecerobohan atau kurang cermat, kesalahan-kesalahan mahasiswa dalam menyelesaikan soal-soal matematika adalah tidak menguasai bahasa, seperti mahasiswa tidak paham dengan pernyataan dalam soal matematika, tidak memahami arti kata, tidak menguasai konsep, dan kurang menguasai teknik berhitung. (2) Weakness in process skill, yaitu kesalahan dalam keterampilan proses, mahasiswa dalam menggunakan kaidah atau aturan sudah benar, tetapi melakukan kesalahan dalam melakukan perhitungan atau komputasi. (3) Reading comprehension difficulty, yaitu kesalahan memahami soal, mahasiswa sebenarnya sudah dapat memahami soal, tetapi belum menangkap informasi yang terkandung dalam pertanyaan, sehingga mahasiswa tidak dapat memproses lebih lanjut solusi dari permasalahan. (4) Transform error, yaitu kesalahan dalam 
transformasi, mahasiswa gagal dalam memahami soal-soal untuk diubah ke dalam kalimat matematika yang benar. (5) Encoding error, yaitu kesalahan dalam menggunakan notasi.

Kesulitan dalam memecahkan masalah turunan dan integral berkaitan erat dengan sudut pandang dari masing-masing mahasiswa, sudut pandang ini akan meningkatkan atau bahkan melemahkan motivasi mahasiswa dalam mempelajari dan memecahkan masalah kalkulus. Menurut Hoyles dalam Wahyuni (2017) bahwa beberapa siswa memandang matematika sebagai subjek yang menyebabkan ketakutan, kecemasan dan kemarahan selama pelajaran. Menurut Subini dalam Haryadi dan Nurmaningsih (2019) bahwa kesulitan belajar merupakan suatu kondisi yang memperlihatkan ciri-ciri hambatan dalam kegiatan untuk mencapai tujuan sehingga diperlukan usaha yang lebih baik untuk mengatasi gangguan tersebut, mahasiswa yang mengalami kesulitan belajar akan sukar dalam menyerap materi-materi pelajaran yang disampaikan oleh dosen sehingga ia akan malas dalam belajar. Adapun menurut Susilawati dalam Seruni (2018) mengatakan bahwa saat ini, pelajaran matematika masih dicitrakan sebagai mata pelajaran tersukar dan terkesan ditakuti oleh sebagian besar peserta didik.

Brousseau dalam Wahyuni (2017) mengemukakan terdapat tiga faktor yang dapat menyebabkan hambatan atau kesulitan belajar yang dialami oleh siswa pada saat proses pembelajaran yaitu: (1) hambatan ontogeni (kesiapan mental belajar), salah satu penyebabnya adalah karena pembatasan konsep pembelajaran pada saat perkembangan anak, (2) hambatan didaktis (akibat pengajaran guru), bisa berasal dari pemberian konsep yang salah ataupun pengajaran konsep yang tidak sesuai dengan kesiapan anak (3) hambatan epistimologis (pengetahuan siswa yang memiliki konteks aplikasi yang terbatas). Penjelasan lebih lanjut oleh Duroux dalam Wahyuni (2017) bahwa epistimological obstacle pada hakekatnya merupakan pengetahuan seseorang yang hanya terbatas pada konteks tertentu, jika orang tersebut dihadapkan pada konteks berbeda, maka pengetahuan yang dimiliki menjadi tidak bisa digunakan atau dia mengalami kesulitan untuk menggunakannya.

Pengetahuan awal yang sangat minim menyebabkan rasa malas dan menganggap sulit kalkulus peubah banyak. Menurut Pazzani (Sulistyorini, 2017) yang menyatakan bahwa pengetahuan awal akan berpengaruh terhadap kemudahan peserta didik dalam memahami konsep selanjutnya. Kesalahan konsep, kesalahan prinsip dan kesalahan operasi menjadi faktor dalam proses pemecahan masalah kalkulus peubah banyak seperti dijelaskan oleh Atim (Nur Afifah, Nafi'an, dan Putri, 2018) meliputi kurangnya latihan soal, tidak memahami konsep diferensial dan integral, menghafal prinsip diferensial dan integral namun tidak memahaminya, prinsip tersebut tidak digunakan dalam menyelesaikan soal, cenderung tidak cermat dan mempersingkat dalam menentukan jawaban akhirnya. Hal ini juga didukung oleh hasil wawancara peneliti dengan mahasiswa selama proses pembelajaran bahwa hampir sebagian besar mahasiswa setelah mendapatkan materi kalkulus peubah banyak, mahasiswa cenderung untuk tidak mereview kembali materi tersebut dan mahasiswa lebih monoton pada contoh soal yang diberikan tanpa ada motivasi untuk mencoba dan berlatih pada soal-soal lain dengan level yang berbeda.

Hasil penelitian yang dilakukan oleh Apriandi dan Krisdiana (2016) menyatakan bahwa terdapat 5 jenis kesulitan mahasiswa dalam memahami integral lipat dua pada kordinat polar, yaitu 1) kesulitan dalam menggambar suatu fungsi pada koordinat polar dan menentukan daerah integrasi, 2) kesulitan dalam mengkonversi variabel ke dalam koordinat polar, 3) kesulitan dalam menentukan batas integrasi, 4) kesulitan dalam menuliskan bentuk integrasi dalam koordinat polar, 5) kesulitan dalam melakukan perhitungan. Hasil penelitian lain oleh Mujib (2017) pada matakuliah kalkulus II menyatakan bahwa terdapat $46 \%$ mahasiswa mengalami miskonsepsi, 53,4\% mahasiswa tidak mengetahui konsep dan 0,6\% mahasiswa yang sama sekali tidak tahu konsep. Adapun hasil penelitian oleh Nur Afifah, Nafi'an, dan Putri (2018) pada matakuliah kalkulus peubah banyak bahwa jenis kesalahan (miskonsepsi) yang dilakukan meliputi jenis kesalahan konsep (aturan rantai dan penggunaan harga mutlak, turunan trigonometri, turunan parsial, konsep integral dan eksponen), kesalahan operasi (perkalian antara koefisien dan variabel dari sebuah fungsi dan operasi bilangan bulat) dan jenis kesalahan prinsip (penulisan rumus aturan rantai). 
Kesulitan dan kesalahan mahasiswa dalam memecahkan masalah kalkulus peubah banyak masih sering dijumpai, untuk itu perlu adanya suatu analisis kesalahan (error anlysis) terhadap jawaban matematis mahasiswa. Tujuan analisis kesalahan mahasiswa adalah melakukan evaluasi pembelajaran sehingga bisa memilih suatu metode yang tepat dan bervariasi dalam proses pembelajaran untuk mencari solusi alternatif sehingga kesalahan tersebut tidak berkelanjutan dan tujuan pembelajaran dapat tercapai maksimal. Hal ini senada dengan yang disampaikan oleh Sahriah dalam Haryadi dan Nurmaningsih (2019) bahwa kesalahan yang dilakukan oleh mahasiswa dapat digunakan sebagai bahan pertimbangan pengajaran dalam usaha meningkatkan kegiatan belajar dan mengajar, adanya peningkatan kegiatan belajar dan mengajar diharapkan dapat memperbaiki hasil belajar atau prestasi belajar mahasiswa.

Menurut Astuty \& Wijayanti dalam Rahmawati (2017) Analisis kesalahan adalah suatu upaya untuk mengamati, menemukan, dan mengklasifikasi kesalahan dengan aturan tertentu. Adapun Menurut Ketterlin-Geller dan Yovanoff dalam Sulistyorini (2017) menyatakan bahwa analisis kesalahan merupakan salah satu metode yang dapat ditempuh untuk mengidentifikasi adanya kesalahpahaman peserta didik dalam mempelajari konsep matematika. Oleh sebab itu, peneliti tertarik untuk meneliti tentang kesalahan-kesalahan yang terjadi ketika mahasiswa memecahkan masalah kalkulus peubah banyak. Setiap proses pemecahan masalah kalkulus peubah banyak sering dijumpai adanya kesalahan-kesalahan yang sering berulang dilakukan oleh mahasiswa. Analisis kesalahan ini perlu adanya metode yang tepat sehingga dosen dapat memberikan yang terbaik untuk keberhasilan proses pembelajaran yang dilakukan.

Salah satu metode untuk menganalisis kesalahan adalah menggunakan metode Newmann's Error Analysis (NEA). Menurut Febriani dan Mukhni (2018) bahwa Analisis kesalahan Newman terdiri dari 5 tahapan, yaitu (1) Kesalahan membaca soal, (2) Kesalahan memahami soal, (3) Kesalahan konfigurasi soal, (4) Kesalahan keterampilan proses, dan (5) Kesalahan menuliskan jawaban akhir. Adapun menurut Nasution (2018) bahwa NEA merupakan metode yang dikembangkan oleh Newmann yang dapat digunakan untuk mengidentifikasi letak kesalahan siswa pada hasil pekerjaannya terutama untuk pelajaran matematika, metode ini menganggap bahwa pekerjaan siswa dapat dikategorikan dalam 5 tahapan yaitu reading, comprehension, transformation, process skill, dan encoding.

\section{METODE}

Penelitian ini merupakan penelitian deskriptif. Tujuan penelitian ini adalah untuk mengetahui letak dan deskripsi kesalahan yang sering dilakukan oleh mahasiswa dengan menggunakan metode Newmann's Error Analysis pada matakuliah kalkulus peubah banyak dan faktor-faktor yang menyebabkan kesalahan tersebut. Subyek penelitian ini adalah mahasiswa semester lima (5) Program Studi Pendidikan Matematika Universitas Indraprasta PGRI Jakarta tahun akademik 2018/2019 sebanyak 47 orang mahasiswa.

Teknik pengumpulan data yang digunakan adalah dokumentasi dan wawancara. Dokumentasi yang dilakukan berupa dokumentasi hasil pekerjaan mahasiswa pada ujian akhir semester (UAS) yang terdiri dari 6 soal. Penelitian ini menggunakan pendekatan kualitatif dan kuantitatif. Adapun pendekatan kualitatitif digunakan ketika menganalisis jawaban mahasiswa dan mengkategorikannya dalam 5 tahapan NEA dan pendekatan kuantitatif yaitu menghitung berapa jumlah mahasiswa yang melakukan tipe kesalahan tertentu pada masing-masing tipe soal. Adapun tipe soal yang dianaslisis disajikan pada tabel 1 sebagai berikut: 
Tabel 1. Tipe Soal UAS Kalkulus Peubah Banyak

\begin{tabular}{|c|c|c|}
\hline Materi & $\begin{array}{l}\text { Nomor } \\
\text { Soal }\end{array}$ & Soal-soal \\
\hline Sistem Koordinat & 1 & $\begin{array}{l}\text { Ubahlah koordinat bola } A\left(16, \frac{2}{3} \pi, \frac{1}{6} \pi\right) \text { menjadi } \\
\text { koordinat tabung dan kartesius. }\end{array}$ \\
\hline $\begin{array}{l}\text { Turunan Fungsi } \\
\text { Dua Peubah }\end{array}$ & 2 & $\begin{array}{l}\text { Jika } w=x^{2}-y^{2}+3 z^{2}+x y z \text { dengan } x=s^{2} t \\
y=2 s+3 t \text { dan } z=4 s-4 t^{2} . \text { Tentukan } \frac{\partial w}{\partial s} !\end{array}$ \\
\hline & 3 & $\begin{array}{l}\text { Tentukan turunan total dari fungsi } f(x, y)= \\
4 x y \cos x+2 x y^{3}\end{array}$ \\
\hline Optimisasi & 4 & Diketahui fungsi $f(x, y, z)=x^{2}+3 y^{2}+2 x y-$ \\
\hline $\begin{array}{l}\text { Menggunakan } \\
\text { Turunan Fungsi }\end{array}$ & & $\begin{array}{l}6 x-8 . \text { Tentukan Nilai ekstrem dan titik ekstrem } \\
\text { dari fungsi tersebut! }\end{array}$ \\
\hline Dua Peubah & 5 & $\begin{array}{l}\text { Tentukan nilai dari fungsi } f(x, y, z)=2 x^{2}+y^{2}+ \\
6 z \text { dengan menggunakan metode lagrange, jika } \\
\text { diketahui } 2 x+y+3 z=6 \text { ! }\end{array}$ \\
\hline Fungsi Gamma & 6 & Hitunglah $\int_{0}^{\infty} 2 x^{3} e^{-3 \sqrt{x}} d x$ \\
\hline
\end{tabular}

Analisis data pada penelitian ini mengikuti pedoman untuk mengkategorikan kesalahan pekerjaan mahasiswa dapat dilihat pada tabel 2. Pedoman ini sejalan dengan pemahaman Junaedi (Nasution, 2018) dengan sedikit revisi beberapa poin oleh peneliti.

Tabel 2. Tahapan NEA Berdasarkan Jenis Kesalahan

\begin{tabular}{ll}
\hline Jenis Tahapan NEA & \multicolumn{1}{c}{ Jenis Kesalahan Mahasiswa } \\
\hline Reading $(R)$ & $\begin{array}{l}\text { Mahasiswa dianggap salah pada bagian ini jika soal tidak dapat } \\
\text { dipahami oleh mahasiswa. }\end{array}$ \\
Comprehension $(C)$ & $\begin{array}{l}\text { Mahasiswa dianggap salah pada bagian ini jika paham semua istilah } \\
\text { pada soal tetapi tidak mengetahui apa yang diminta oleh soal. }\end{array}$ \\
Transformation $(T)$ & $\begin{array}{l}\text { Mahasiswa dianggap salah pada bagian ini jika tahu harus mencari } \\
\text { apa tetapi tidak mengerti bagaimana caranya. }\end{array}$ \\
Process Skill (PS) & $\begin{array}{l}\text { Mahasiswa dianggap salah pada bagian ini jika tahu cara untuk } \\
\text { menyelesaikan soal tetapi mereka tidak bisa menyelesaikannya } \\
\text { dengan benar. } \\
\text { Mahasiswa dianggap salah pada bagian ini jika tidak dapat } \\
\text { menuliskan kesimpulan dan jawaban akhir dengan benar. }\end{array}$ \\
\hline
\end{tabular}

\section{HASIL}

Setelah melakukan analisis awal dengan memeriksa hasil pekerjaan mahasiswa, diketahui bahwa terdapat beberapa mahasiswa yang sama sekali tidak mengerjakan soal dan memberikan jawaban yang menunjukkan ketidakpahaman. Untuk kasus ini, peneliti dapat memasukkannya ke dalam kategori reading dikarenakan mahasiswa tidak mampu memahami soal dengan baik. 
1. Deskripsi Kesalahan Mahasiswa Pada Materi Sistem Koordinat

Tabel 3. Deskripsi Kesalahan Mahasiswa Soal Nomor 1

\begin{tabular}{clcc}
\hline $\begin{array}{c}\text { Tahapan } \\
\text { NEA }\end{array}$ & \multicolumn{1}{c}{ Contoh Kesalahan Mahasiswa } & $\begin{array}{c}\text { Frekuensi } \\
\text { (orang) }\end{array}$ \\
\hline$R$ & $\begin{array}{l}\text { Mahasiswa tidak mengerjakan atau memberikan isian yang } \\
\text { menunjukkan ketidakpahaman konsep. }\end{array}$ & 4 \\
$C$ & $\begin{array}{l}\text { Mahasiswa menuliskan formula kurang tepat. } \\
\text { Mahasiswa hanya menuliskan formula tetapi tidak paham proses }\end{array}$ & 1 \\
$T$ & $\begin{array}{l}\text { pemecahan berikutnya. } \\
\text { Mahasiswa melakukan kesalahan pada penggunaan formula pada }\end{array}$ & 25 \\
& $\begin{array}{l}\text { proses aljabar (kesalahan menentukan nilai sudut trigonometri) } \\
E S\end{array} \quad$ Kesalahan menuliskan kesimpulan atau tidak menuliskan kesimpulan. & 4 \\
\hline Mahasiswa tidak melakukan kesalahan & 12 \\
\hline Jumlah Mahasiswa & 47 \\
\hline
\end{tabular}
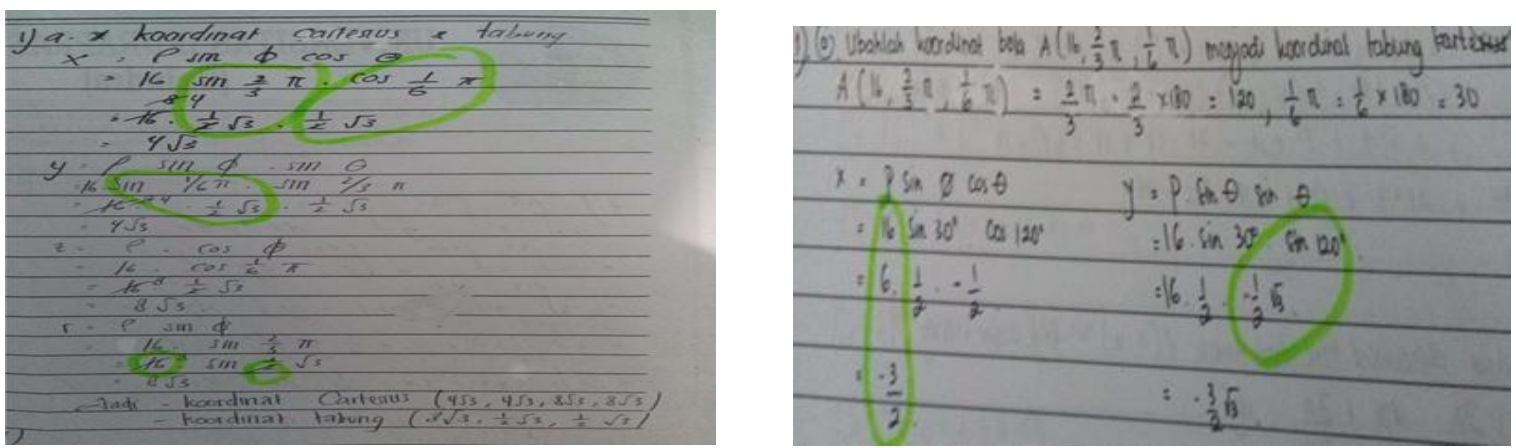

Gambar 1. Kesalahan Tahapan Process Skill

2. Deskripsi Kesalahan Mahasiswa Pada Materi Turunan Fungsi Dua Peubah

Materi turunan fungsi dua peubah terdapat pada tipe soal nomor 2 dan nomor 3 . Deskripsi kesalahan mahasiswa pada tipe soal nomor 2 dan nomor 3 disajikan pada tabel 4 dan tabel 5 sebagai berikut:

Tabel 4. Deskripsi Kesalahan Mahasiswa Soal Nomor 2

\begin{tabular}{|c|c|c|}
\hline $\begin{array}{l}\text { Tahapan } \\
\text { NEA }\end{array}$ & Contoh Kesalahan Mahasiswa & $\begin{array}{l}\text { Frekuensi } \\
\text { (orang) }\end{array}$ \\
\hline$R$ & $\begin{array}{l}\text { Mahasiswa tidak mengerjakan atau memberikan isian yang menunjukkan } \\
\text { ketidakpahaman konsep. }\end{array}$ & 2 \\
\hline$C$ & $\begin{array}{l}\text { Mahasiswa hanya menuliskan } \frac{\partial w}{\partial s}=\frac{\partial w}{\partial x} \cdot \frac{\partial x}{\partial s}+\frac{\partial w}{\partial y} \cdot \frac{\partial y}{\partial s} \\
\text { atau menuliskan formula yang kurang tepat } \frac{\partial w}{\partial s}=\frac{\partial w}{\partial x} \cdot \frac{\partial x}{\partial t}+\frac{\partial w}{\partial y} \cdot \frac{\partial y}{\partial t}+\frac{\partial w}{\partial z} \cdot \frac{\partial z}{\partial t}\end{array}$ & 18 \\
\hline$T$ & $\begin{array}{l}\text { Mahasiswa menuliskan formula yang tepat tetapi salah dalam menentukan } \\
\text { turunan } \frac{\partial w}{\partial x}, \frac{\partial w}{\partial y}, \frac{\partial w}{\partial z}, \frac{\partial x}{\partial s}, \frac{\partial y}{\partial s} \text { dan } \frac{\partial z}{\partial s} \text {. }\end{array}$ & 20 \\
\hline$P S$ & $\begin{array}{l}\text { Mahasiswa memahami penggunaan formula tetapi proses penjabaran } \\
\text { formula yang kurang tepat. }\end{array}$ & 3 \\
\hline$E$ & $\begin{array}{l}\text { Mahasiswa memperoleh hasil penjabaran formula tetapi tidak spesifik } \\
\text { dalam bentuk yang sederhana. }\end{array}$ & 1 \\
\hline \multicolumn{2}{|c|}{ Mahasiswa tidak melakukan kesalahan } & 3 \\
\hline \multicolumn{2}{|c|}{ Jumlah Mahasiswa } & 47 \\
\hline
\end{tabular}



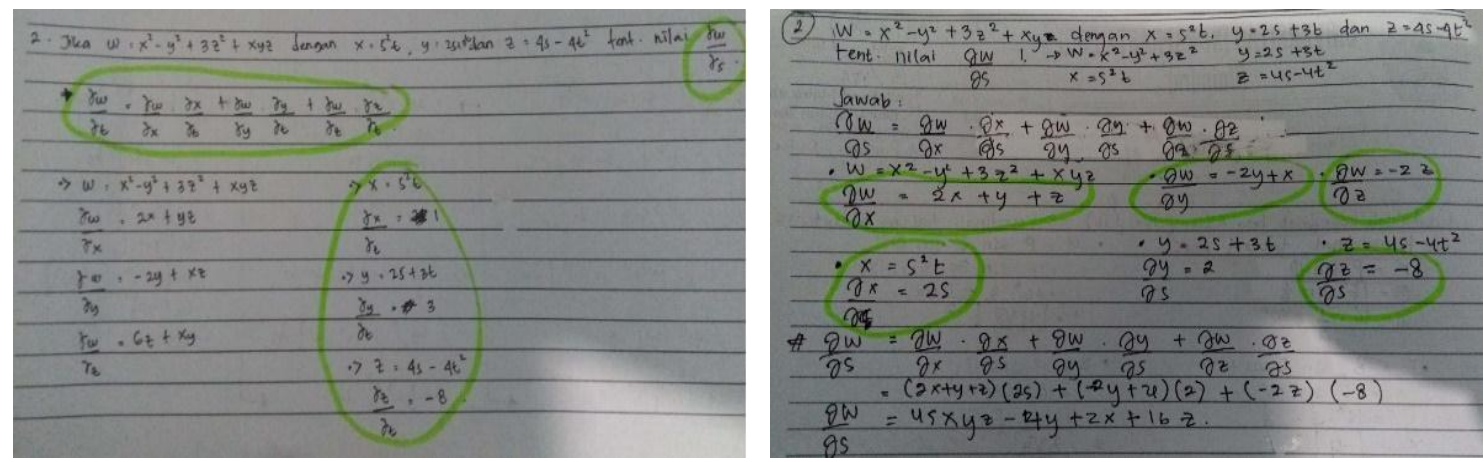

Gambar 2. Kesalahan Tahapan Comprehension dan Transformation

Tabel 5. Deskripsi Kesalahan Mahasiswa Soal Nomor 3

\begin{tabular}{clc}
\hline $\begin{array}{c}\text { Tahapan } \\
\text { NEA }\end{array}$ & \multicolumn{1}{c}{ Contoh Kesalahan Mahasiswa } & $\begin{array}{c}\text { Frekuensi } \\
\text { (orang) }\end{array}$ \\
\hline$R$ & $\begin{array}{l}\text { Mahasiswa tidak mengerjakan atau memberikan isian yang menunjukkan } \\
\text { ketidakpahaman konsep. }\end{array}$ & 8 \\
$C$ & $\begin{array}{l}\text { Mahasiswa menuliskan formula yang kurang tepat. } \\
T\end{array}$ & 5 \\
& Kesalahan menentukan turunan dari $\frac{\partial f}{\partial x}$ dan $\frac{\partial f}{\partial y}$ & 25 \\
& $\begin{array}{l}\text { Mahasiswa memahami penggunaan formula tetapi proses penjabaran } \\
\text { formula kurang tepat. }\end{array}$ & 3 \\
& $\begin{array}{l}\text { Mahasiswa tidak menuliskan kesimpulan jawaban dengan jawaban yang } \\
\text { lebih spesifik }\end{array}$ & 2 \\
\hline Mahasiswa tidak melakukan kesalahan & 4 \\
\hline Jumlah Mahasiswa & 47 \\
\hline
\end{tabular}
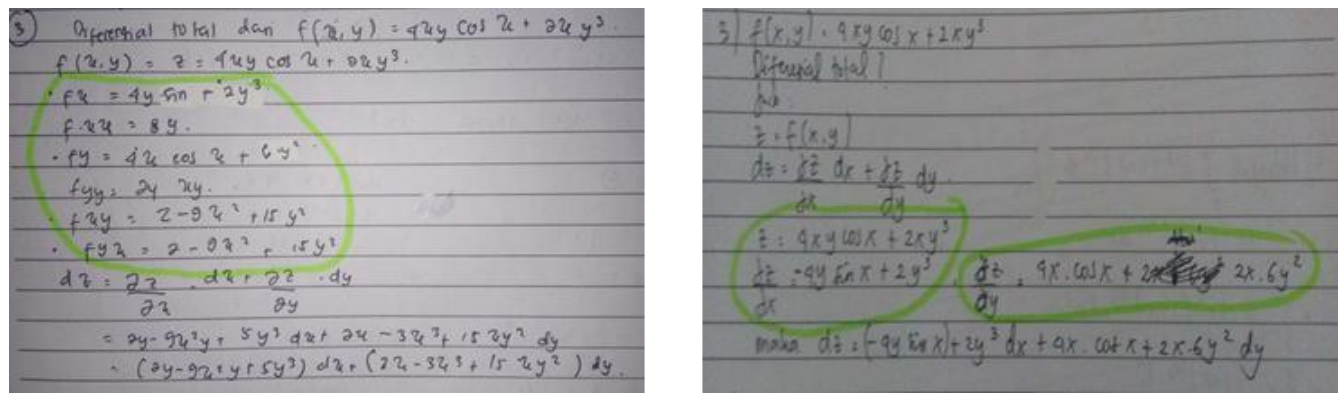

Gambar 3. Kesalahan Tahapan Transformation

3. Deskripsi Kesalahan Mahasiswa Pada Materi Optimisasi Menggunakan Turunan Fungsi Dua Peubah.

Materi turunan fungsi dua peubah terdapat pada tipe soal nomor 4 dan nomor 5 . Deskripsi kesalahan mahasiswa pada tipe soal nomor 4 dan nomor 5 disajikan pada tabel 6 dan tabel 7 sebagai berikut: 
Tabel 6. Deskripsi Kesalahan Mahasiswa Soal Nomor 4

\begin{tabular}{|c|c|c|}
\hline $\begin{array}{l}\text { Tahapan } \\
\text { NEA }\end{array}$ & Contoh Kesalahan Mahasiswa & $\begin{array}{l}\text { Frekuensi } \\
\text { (orang) }\end{array}$ \\
\hline$R$ & $\begin{array}{l}\text { Mahasiswa tidak mengerjakan atau memberikan isian yang menunjukkan } \\
\text { ketidakpahaman konsep. }\end{array}$ & 16 \\
\hline$C$ & Kesalahan menentukan turunan dari $f_{x}$ dan $f_{y}$ & 4 \\
\hline$T$ & Mahasiswa tidak paham tahapan berikutnya setelah memperoleh $f_{x}$ dan $f_{y}$. & 0 \\
\hline$P S$ & $\begin{array}{l}\text { Kesalahan dalam proses aljabar (substitusi dan eliminasi) setelah } \\
\text { memperoleh } f_{x} \text { dan } f_{y} \text { untuk memperoleh titik ekstrim atau Kesalahan }\end{array}$ & \\
\hline & $\begin{array}{l}\text { dalam menentukan ada tidaknya ekstrim } \Delta=f_{x x} \cdot f_{y y}-\left(f_{x y}\right)^{2} \text { atau } \\
\text { kesalahan menentukan ekstrim minimum atau maksimum }\left(f_{x x}>\right. \\
\left.0 \text { atau } f_{x x}<0\right)\end{array}$ & 15 \\
\hline$E$ & $\begin{array}{l}\text { Kesalahan dalam memberikan kesimpulan hasil akhir dari harga ekstrim } \\
f(x, y) \text {. }\end{array}$ & 5 \\
\hline \multicolumn{2}{|c|}{ Mahasiswa tidak melakukan kesalahan } & 7 \\
\hline \multicolumn{2}{|c|}{ Jumlah Mahasiswa } & 47 \\
\hline
\end{tabular}
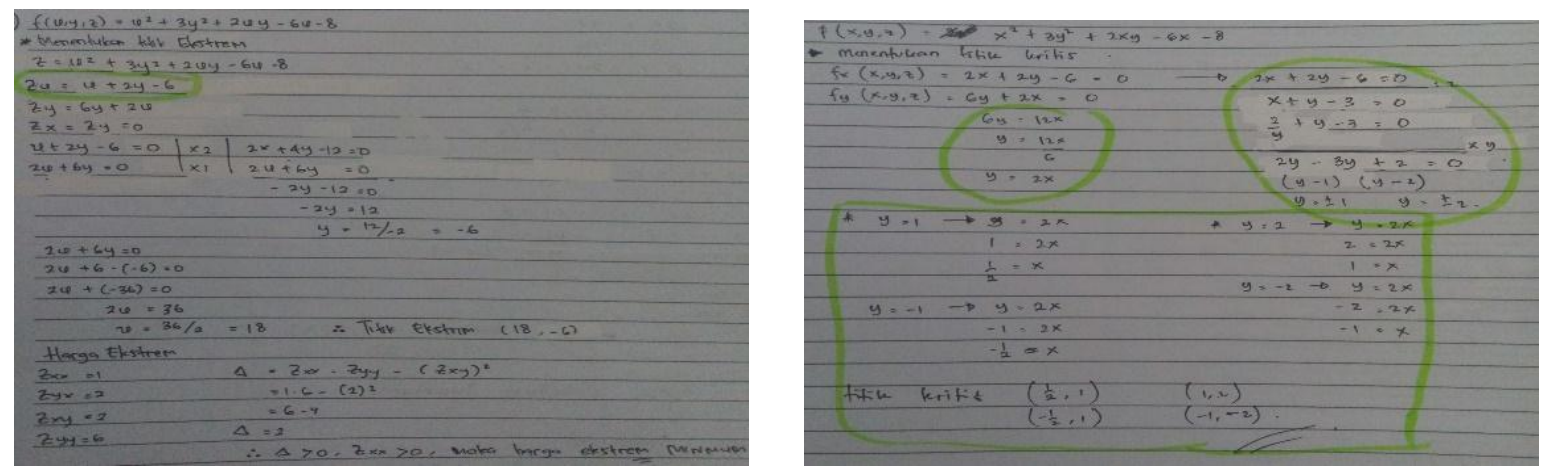

Gambar 4. Kesalahan Tahapan Comprehension dan Process Skill

Tabel 7. Deskripsi Kesalahan Mahasiswa Soal Nomor 5

\begin{tabular}{clc}
\hline $\begin{array}{c}\text { Tahapan } \\
\text { NEA }\end{array}$ & \multicolumn{1}{c}{ Contoh Kesalahan Mahasiswa } & $\begin{array}{c}\text { Frekuensi } \\
\text { (orang) }\end{array}$ \\
\hline$R$ & $\begin{array}{l}\text { Mahasiswa tidak mengerjakan atau memberikan isian yang } \\
\text { menunjukkan ketidakpahaman konsep. }\end{array}$ & 10 \\
$C$ & $\begin{array}{l}\text { Mahasiswa menuliskan formula yang kurang tepat atau substitusi } \\
f(x, y, z) \text { dan } g(x, y, z) \text { kedalam formula kurang tepat }\end{array}$ & 5 \\
$T$ & $\begin{array}{l}\text { Hanya menuliskan } L(x, y, \lambda) \text { dengan benar tetapi tidak melanjutkan } \\
\text { ke tahapan berikutnya atau kesalahan dalam menentukan } \frac{\partial L}{\partial x}=0,\end{array}$ & 12 \\
& $\begin{array}{l}\partial L \\
\partial y\end{array}=0 \frac{\partial L}{\partial z}=0$ dan $\frac{\partial L}{\partial \lambda}=G(x, y)=0$ \\
& $\begin{array}{l}\text { Kesalahan dalam proses aljabar (substitusi dan eliminasi) } \\
\text { menentukan titik kritis }(x, y, z, \lambda) \text { atau tidak (salah) menentukan }\end{array}$ & 12 \\
& $\begin{array}{l}\text { jenis ekstrim. } \\
\text { Kesalahan dalam memberikan kesimpulan hasil akhir dari harga } \\
\text { ekstrim } L(x, y, \lambda) \equiv f(x, y, z)+\lambda G(x, y, z)\end{array}$ & 1 \\
\hline Mahasiswa tidak melakukan kesalahan & 7 \\
\hline Jumlah Mahasiswa
\end{tabular}



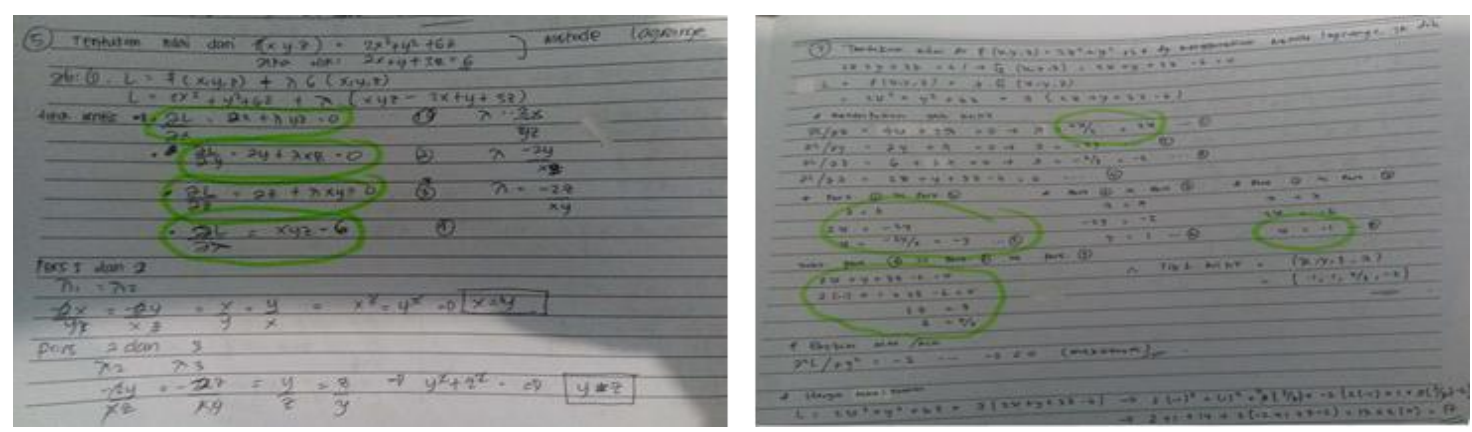

Gambar 5. Kesalahan Tahapan Transformartion dan Process Skill

4. Deskripsi Kesalahan Mahasiswa Pada Materi Fungsi Gamma

Tabel 8. Deskripsi Kesalahan Mahasiswa Soal Nomor 6

\begin{tabular}{clc}
\hline $\begin{array}{c}\text { Tahapan } \\
\text { NEA }\end{array}$ & \multicolumn{1}{c}{ Contoh Kesalahan Mahasiswa } & $\begin{array}{c}\text { Frekuensi } \\
\text { (orang) }\end{array}$ \\
\hline$R$ & $\begin{array}{l}\text { Mahasiswa tidak mengerjakan atau beberapa isian yang diberikan } \\
\text { menunjukkan ketidakpahaman terhadap soal. }\end{array}$ & 41 \\
$C \quad$ & $\begin{array}{l}\text { Mahasiswa melakukan kesalahan manipulasi aljabar bentuk } \\
\text { permisalan } u=3 \sqrt{x} \text { atau kesalahan memberikan permisalan } \\
\text { dengan } u=-3 \sqrt{x}\end{array}$ & 5 \\
& $\begin{array}{l}\text { Mahasiswa memanipulasi bentuk } u=3 \sqrt{x} \text { tetapi tidak paham } \\
\text { proses integrasi berikutnya. }\end{array}$ & 0 \\
& $\begin{array}{l}\text { Mahasiswa memahami proses integrasi akan tetapi proses } \\
\text { integrasi yang diberikan tidak tepat }\end{array}$ & 0 \\
& $\begin{array}{l}\text { Mahasiswa melakukan proses integrasi tepat tidak memberikan } \\
\text { jawaban akhir yang tepat. }\end{array}$ & 0 \\
\hline Mahasiswa tidak melakukan kesalahan & 1 \\
\hline Jumlah Mahasiswa & 47 \\
\hline
\end{tabular}
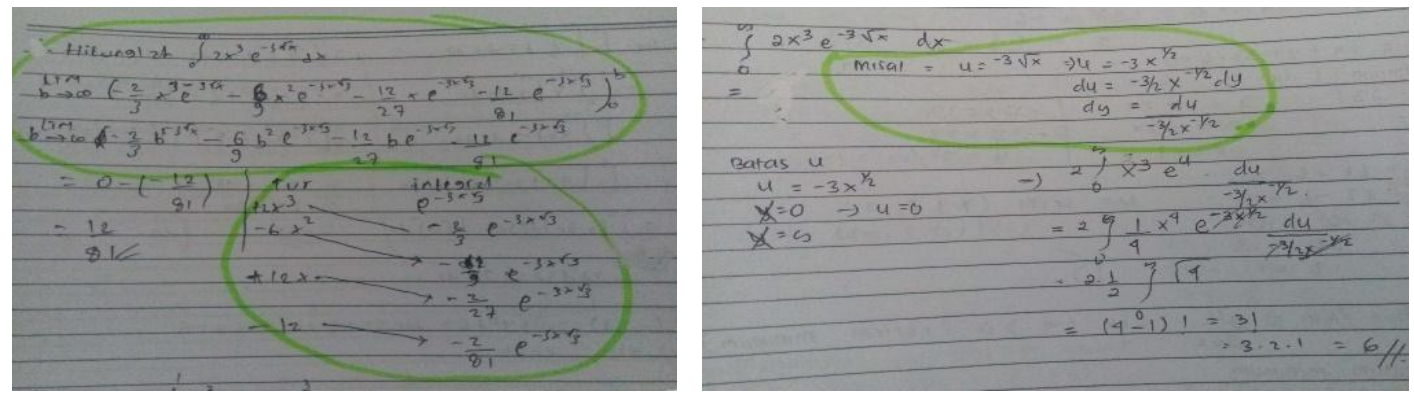

Gambar 6. Kesalahan Tahapan Reading dan Comprehension

\section{PEMBAHASAN}

Analisis kesalahan mahasiswa pada matakuliah kalkulus peubah banyak ini dilakukan dengan menganalisis masing-masing butir soal berdasarkan sub materi kalkulus peubah banyak yang bertujuan untuk mengetahui tingkat penguasaan konsep dan jenis kesalahan yang dilakukan oleh mahasiswa. Adapun analisis yang dilakukan sebagai berikut: 
1. Analisis Kesalahan Mahasiswa Pada Materi Sistem Koordinat

Materi sistem koordinat terdapat pada tipe soal nomor 1, mahasiswa diminta untuk merubah bentuk dari koordinat bola $(\rho, \theta, \phi)$ menjadi koordinat tabung $(r, \theta, z)$ dan koordinat kartesius $(x, y, z)$. Formula yang dapat digunakan untuk merubah dari koordinat bola ke koordinat tabung adalah $r=\rho \sin \phi, \theta=\theta, z=\rho \cos \phi$. Adapun formula untuk merubah dari koordinat bola ke koordinat kartesius adalah $x=\rho \sin \phi \cdot \cos \theta, y=\rho \sin \phi \cdot \sin \theta, \quad z=$ $\rho \cos \phi$. Proses perubahan koordinat ini membutuhkan kemampuan aljabar dan penggunaan formula yang tepat.

Pada tabel 3 terlihat bahwa kesalahan terbanyak mahasiswa pada soal nomor 1 adalah pada tahapan process skill sebanyak 25 mahasiswa. Kesalahan pada tahapan process skill ini adalah pada proses aljabar untuk menentukan nilai sudut misalnya mahasiswa menuliskan $\cos \frac{2}{3} \pi=\frac{1}{2}$ yang seharusnya $\cos \frac{2}{3} \pi=-\frac{1}{2}$ dan $\sin \frac{2}{3} \pi=-\frac{1}{2} \sqrt{3}$ yang seharusnya $\sin \frac{2}{3} \pi=\frac{1}{2} \sqrt{3}$. Kesalahan lain adalah beberapa mahasiswa menuliskan sudut $\theta=\frac{2}{3} \pi$ dan $\phi=\frac{1}{6} \pi$ saling tertukar misalnya $x=16 \sin \frac{2}{3} \pi \cdot \cos \frac{\pi}{6}$ yang seharusnya $x=\sin \frac{\pi}{6} \cdot \cos \frac{2}{3} \pi$. Kesalahan-kesalahan pada tahapan process skill dapat lihat pada gambar 1. Dengan demikian, ketelitian dalam memahami konsep atau formula sistem koordinat dan sudut pada trigonometri sangat diperlukan untuk memecahkan masalah nomor 1 .

2. Analisis Kesalahan Mahasiswa Pada Materi Turunan Fungsi Dua Peubah

Materi turunan fungsi dua peubah terdapat pada tipe soal nomor 2 dan nomor 3. Soal nomor 2 merupakan sub materi turunan fungsi dari suatu fungsi yaitu mahasiswa diminta untuk menentukan turunan fungsi $w$ terhadap $s\left(\frac{\partial w}{\partial s}\right)$ yaitu dengan menggunakan formula $\frac{\partial w}{\partial s}=\frac{\partial w}{\partial x}$. $\frac{\partial x}{\partial s}+\frac{\partial w}{\partial y} \cdot \frac{\partial y}{\partial s}+\frac{\partial w}{\partial z} \cdot \frac{\partial z}{\partial s}$. Penggunaan formula ini tidak terlepas dari pemahaman mahasiswa terhadap bentuk turunan. Pemahaman terhadap materi turunan pada kalkulus differensial akan sangat membantu mahasiswa untuk menyelesaikan dan memecahkan soal nomor 2, ketidakpahaman akan menyebabkan mahasiswa melakukan kesalahan konsep. Kesalahan yang sering ditemui pada soal nomor 2 adalah pada tahapan Comprehension (kesalahan dalam menentukan formula yang tepat) dan Transformation (kesalahan dalam menurunkan suatu fungsi berdasarkan formula).

Pada tabel 4 terlihat bahwa kesalahan terbanyak mahasiswa pada soal nomor 2 adalah pada tahapan transformation sebanyak 20 mahasiswa dan tahapan Comprehension sebanyak 18 mahasiswa. Kesalahan pada tahapan transformation adalah kesalahan dalam konsep turunan, adapun pada tahapan Comprehension, kesalahan dalam menentukan formula yang tepat sesuai dengan pertanyaan soal. Pada tahapan transformation banyak diantara mahasiswa menuliskan turunan dari $\frac{\partial x}{\partial s}=s$ dan ada juga yang menuliskan $\frac{\partial x}{\partial s}=s t$. Secara konsep turunan, hasil dari $\frac{\partial x}{\partial s}=2 s t$, hal ini menunjukkan bahwa secara konsep turunan, mahasiswa kurang mampu memahami materi turunan dengan baik. Kesalahan berikutnya adalah menentukan formula yang tepat, banyak diantara mahasiswa menuliskan $\frac{\partial w}{\partial s}=\frac{\partial w}{\partial x} \cdot \frac{\partial x}{\partial t}+\frac{\partial w}{\partial y} \cdot \frac{\partial y}{\partial t}+\frac{\partial w}{\partial z} \cdot \frac{\partial z}{\partial t}$. Secara konsep rumus tersebut digunakan apabila pertanyaannya adalah menentukan $\frac{\partial w}{\partial t}$. Lebih jelasnya kesalahan-kesalahan pada tahapan Comprehension dan Transformation dapat dilihat pada gambar 2. Beberapa kesalahan tersebut menunjukkan bahwa mahasiswa tidak memahami pertanyaan soal dengan baik, tidak memahami konsep formula yang tepat yang digunakan dan salah dalam memahami konsep turunan.

Adapun pada soal nomor 3 merupakan sub materi turunan total yaitu mahasiswa diminta untuk menentukan turunan total dari fungsi $f(x, y)=4 x y \cos x+2 x y^{3}$ dengan menggunakan 
formula $d f=\frac{\partial f}{\partial x} d x+\frac{\partial f}{\partial y} d y$. Kesalahan yang sering ditemui adalah kesalahan pada tahapan transformasi yaitu kesalahan mahasiswa dalam menentukan turunan fungsi trigonometri. Mahasiswa sering mengalami kesulitan dalam menentukan turunan trigonometri, hal ini berdasarkan konfirmasi selama proses pembelajaran bahwa rata-rata mahasiswa menyatakan trigonometri terlalu banyak formula dan rumit untuk dipahami.

Pada tabel 5 terlihat bahwa kesalahan terbanyak mahasiswa adalah pada tahapan transformation yaitu sebanyak 25 mahasiswa melakukan kesalahan pada konsep turunan parsial yaitu menentukan turunan dari $\frac{\partial f}{\partial x}$ dan $\frac{\partial f}{\partial y}$. Sebagian mahasiswa yang melakukan kesalahan pada tahapan transformasi menuliskan hasil dari $\frac{\partial f}{\partial x}=-4 y \sin x+2 y^{3}$ dan $\frac{\partial f}{\partial y}=4 x \cos x-$ $\sin \cos x+3 y^{2}$. Hal ini menunjukkan bahwa sebagian besar mahasiswa tidak memahami konsep turunan bentuk $u \cdot v=u^{\prime} \cdot v+v^{\prime} u$, secara konsep turunan, hasil dari turunan $\frac{\partial f}{\partial x}=$ $4 y \cos x-4 x y \sin x+2 y^{3}$ dan $\frac{\partial f}{\partial y}=4 x \cos x+6 x y^{2}$. Lebih detailnya, kesalahan pada tahapan transformasi dapat dilihat pada gambar 3. Dengan demikan, memahami konsep turunan trigonometri sangat penting untuk memecahkan soal nomor 3 sehingga kesalahan-kesalahan yang terjadi dapat diminimalisir.

3. Analisis Kesalahan Mahasiswa Pada Materi Optimisasi Menggunakan Turunan Fungsi Dua Peubah

Materi turunan fungsi dua peubah terdapat pada tipe soal nomor 4 dan nomor 5. Soal nomor 4 merupakan sub materi menentukan harga ekstrim suatu fungsi $f(x, y, z)=x^{2}+3 y^{2}+$ $2 x y-6 x-8$ yaitu dengan menggunakan beberapa proses tahapan penyelesaian. Tahapan peneyelesaian tersebut dimulai dari menentukan titik kritis yaitu menentukan turunan pertama dari $f_{x}=0$ dan $f_{y}=0$, selanjutnya melakukan proses aljabar substitusi dan eliminasi untuk menentukan titik stasioner atau titik kritis yaitu $(x, y)$, berikutnya mengecek ada tidaknya ekstrim dengan formula $\Delta=f_{x x} \cdot f_{y y}-\left(f_{x y}\right)^{2}$, jika ada ekstrim maka pengecekan berikutnya adalah menentukan ekstrim minimum atau ekstrim maksimum dengan $f_{x x}>0$ (minimum) atau $f_{x x}<0$ (maksimum) dan teakhir adalah menentukan harga ekstrim dengan substitusi titik stasioner kedalam $F(x, y)$.

Pada tabel 6 terlihat bahwa kesalahan terbanyak mahasiswa pada soal nomor 4 adalah pada tahapan reading sebanyak 16 mahasiswa dan tahapan process skill sebanyak 15 mahasiswa. Kesalahan pada tahapan reading disebabkan karena mahasiswa tidak memahami maksud soal dan mahasiswa tidak memahami konsep menentukan harga ekstrim dari fungsi $f(x, y, z)$ dan sebagian kecil dari mahasiswa hanya menuliskan kembali soal nomor 4 serta memberikan jawaban yang menunjukkan ketidakpahaman. Adapun kesalahan pada tahapan process skill menunjukkan bahwa mahasiswa telah mampu memahami soal dengan baik yaitu mampu menentukan turunan dari $f_{x}$ dan $f_{y}$ dengan benar, akan tetapi mahasiswa melakukan kesalahan pada saat proses aljabar (eliminasi dan substitusi) untuk menentukan titik ekstrim yaitu nilai $(x, y)$ dan kesalahan lain dalam menentukan ada tidaknya ekstrim karena diharuskan untuk menentukan $f_{x x}, f_{y y}$ dan $f_{x y}$ serta sebagian kecil mahasiswa melakukan kesalahan dalam menentukan ekstrim maksimum atau ekstrim minimum seperti pada gambar 4. Kesalahan pada tahapan Comprehension yaitu mahasiswa tidak memahami konsep turunan untuk menentukan $f_{x}$ dan $f_{y}$. Secara konsep $f_{x}=2 x+2 y-6=0$ dan $f_{y}=2 x+6 y=0$. Sebagian mahasiswa menuliskan $f_{x}=x+2 y-6=0$, hal ini menunjukkan pemahaman konsep turunan masih sangat lemah. Pada tahapan Encoding, kesalahan yang sering di jumpai adalah kesalahan dalam proses substitusi nilai titik ekstrim kedalam fungsi $f(x, y)$ dan penjumlahan setelah proses substitusi. Dengan demikian, kesalahan pada nomor 4 yang sering muncul adalah kesalahan konsep harga ekstrim dan kesalahan konsep turunan. 
Adapun soal nomor 5 merupakan sub materi metode pengali lagrange, mahasiswa diminta untuk menentukan harga ekstrim dari fungsi $f(x)$ dengan menggunakan formula pengali lagrange yaitu $L(x, y, \lambda) \equiv f(x, y, z)+\lambda G(x, y, z)$ dimana; $\frac{\partial L}{\partial x}=0, \frac{\partial L}{\partial y}=0 \quad \frac{\partial L}{\partial z}=0$ dan $\frac{\partial L}{\partial \lambda}=$ $G(x, y)=0$. Pada tabel 7 terlihat bahwa kesalahan terbanyak mahasiswa pada soal nomor 5 adalah pada tahapan transformartion sebanyak 12 mahasiswa, tahapan process skill sebanyak 12 mahasiswa dan tahapan reading sebanyak 10 mahasiswa. Kesalahan yang sering dijumpai pada tahapan transformasi adalah kesalahan mahasiswa pada proses turunan untuk menentukan $\frac{\partial L}{\partial x}, \frac{\partial L}{\partial y}$, $\frac{\partial L}{\partial z}$ dan $\frac{\partial L}{\partial \lambda}$ yang merupakan bentuk turunan sederhana. Kesalahan yang sering dijumpai pada tahapan process skill adalah kesalahan pada proses eliminasi dari persamaan $\frac{\partial L}{\partial x}=0, \frac{\partial L}{\partial y}=0$ $\frac{\partial L}{\partial z}=0$ dan $\frac{\partial L}{\partial \lambda}=G(x, y)=0$ untuk menentukan titik ekstrim $(x, y, z, \lambda)$. Kesalahan lain pada tahapan process skill adalah mahasiswa tidak menentukan jenis ekstrim yang akan dicari dengan $f_{x x}>0$ atau $f_{x x}<0$, sebagian besar langsung menentukan nilai harga ekstrim seperti yang terlihat pada gambar 5. Adapun kesalahan pada tahapan reading adalah mahasiswa tidak memahami konsep formula pengali lagrange dengan baik sehingga mahasiswa tidak mampu memecahkan masalah dan sebagian lain hanya memberikan jawaban yang menunjukkan ketidakpahaman terhadap konsep. Dengan demikian, kesalahan pada soal nomor 5 adalah kesalahan konsep pengali lagrange, kesalahan proses turunan dan kesalahan pada proses aljabar (eliminasi dan substitusi).

4. Analisis Kesalahan Mahasiswa Pada Materi Fungsi Gamma

Materi fungsi gamma terdapat pada tipe soal nomor 6, mahasiswa diminta untuk menyelesaikan bentuk integral yang tak wajar dengan menggunakan konsep fungsi gamma, dimana bentuk soal $\int_{0}^{\infty} 2 x^{3} e^{-3 \sqrt{x}} d x$ harus diubah atau dimanipulasi secara aljabar menjadi bentuk umum fungsi gamma yaitu $\Gamma(n)=\int_{0}^{\infty} e^{-x} \cdot x^{n-1} d x=(n-1)$ ! dengan $(n>0)$. Pada tabel 8 terlihat bahwa kesalahan terbanyak mahasiswa pada soal nomor 6 adalah pada tahapan Reading yaitu sebanyak 41 mahasiswa.

Berdasarkan hasil analisis jawaban mahasiswa menunjukkan bahwa mahasiswa tidak memahami maksud soal, sebagian besar tidak menjawab sama sekali atau hanya menulis kembali soal serta memberikan isian yang menunjukkan ketidakpahaman terhadap pertanyaan soal dan salah konsep misalnya beberapa mahasiswa menjawab soal dengan menggunakan konsep integral parsial. Pada tahapan comprehension sebanyak 5 mahasiswa melakukan kesalahan dalam manipulasi bentuk aljabar dengan permisalan $u=3 \sqrt{x}$, kesalahan yang ditemukan adalah permisalan yang diberikan adalah $u=-3 \sqrt{x}$. Secara konsep permisalan seharusnya adalah $u=$ $3 \sqrt{x}$ kemudian diturunkan terhadap $x$ sehingga $d u=\frac{3}{2 \sqrt{x}} d x$ dan $d x=\frac{2 \sqrt{x}}{3} d u$. Selain kesalahan memberikan permisalahan, kesalahan yang sering muncul adalah kesalahan konsep turunan. Kesalahan pada tahapan reading dan comprehension lebih jelas dapat dilihat pada gambar 6 . Dengan demikian, kesalahan yang dilakukan mahasiswa pada soal nomor 6 adalah tidak memahami konsep fungsi gamma dengan baik dan benar sehingga mahasiswa tidak mampu membedakan mana bentuk soal yang mengarah ke bentuk fungsi gamma atau bukan. 


\section{SIMPULAN}

Berdasarkan hasil pembahasan, maka dapat disimpulkan bahwa jenis kesalahan yang sering dilakukan mahasiswa dalam menyelesaikan soal kalkulus peubah banyak berdasarkan Newmann's Error Analysis meliputi jenis kesalahan pada tahapan reading, tahapan transformasi dan tahapan process skill yaitu kesalahan memahami soal, kesalahan dalam menentukan formula yang tepat, kesalahan konsep (kesalahan dalam menentukan turunan aljabar dan trigonometri, proses eliminasi dan substitusi serta kesalahan dalam manipulasi bentuk aljabar) dan kesalahan perhitungan. Adapun faktor-faktor yang menyebabkan mahasiswa melakukan kesalahan yaitu kurang memahami soal, kurang memahami konsep turunan, integral dan proses eliminasi-substitusi, kurang teliti dan kecerobohan dalam proses perhitungan dan yang paling penting adalah kurang latihan mengerjakan soal-soal dengan bentuk yang bervariasi. Untuk meminimalisir kesalahan-kesalahan ini maka dosen perlu menerapkan beberapa teknik atau metode yang tepat dan bervariasi agar kesalahan dapat diminimalisir dan tidak terulang lagi kesalahan yang sama. Selain itu, perlu kiranya untuk memperkuat konsep turunan dan integral pada matakuliah kalkulus differensial dan kalkulus integral, bila perlu kajian konsep turunan dan integral lebih diperdalam. Sisi lain, pada awal pertemuan, dosen perlu mengadakan pretest dengan memberikan beberapa soal tentang turunan dan integral sehingga secara tidak langsung akan mengarahkan mahasiswa untu membuka kembali (mereview) materi-materi tentang turunan dan integral yang telah dipelajari. Pada saat proses pembelajaran atau setiap sesi pertemuan perkuliahan dosen mengupayakan untuk selalu memberikan motivasi kepada mahasiswa agar terus berusaha dan berlatih menyelesaikan soal-soal kalkulus peubah banyak dengan level kesulitan yang berbeda. Nasehat motivasi yang terus disampaikan secara continue akan memberikan penguatan kepada mahasiswa dan menujukkan rasa kepeduliaan yang tinggi akan keberhasilan mahasiswa.

\section{DAFTAR RUJUKAN}

Apriandi, D. \& Krisdiana, I. (2016). Analisis Kesulitan Mahasiswa dalam Memahami Materi Integral Lipat Dua pada Koordinat Polar Mata Kuliah Kalkulus Lanjut. Al-Jabar: Jurnal Pendidikan Matematika, 7(2): 123-134. Diambil dari http://ejournal.radenintan.ac.id/index.php/al-jabar/article/view/19.

Febriani, D. E. \& Mukhni. (2018). Analisis Kesalahan Siswa dalam Menyelesaikan Soal Cerita Matematika Berdasarkan Analisis Kesalahan Newman pada Siswa Kelas VIII SMP Negeri 7 Padang. Jurnal Edukasi dan Penelitian Matematika, 7(4): 24-29. Diambil dari http://ejournal.unp.ac.id/students/index.php/pmat/article/view/5563.

Farhan, M. \& Retnawati, H. (2014). Keefektifan PBL dan IBL Ditinjau dari Prestasi Belajar, Kemampuan Representasi Matematis, dan Motivasi Belajar. Jurnal Riset Pendidikan Matematika, 1(2): 227-240. Diambil dari https://doi.org/10.21831/jrpm.v1i2.2678.

Hakim, A. R. (2016). Prestasi Belajar Matematika Ditinjau dari Sikap dan Komitmen Diri Peserta Didik pada Pelajaran Matematika. JKPM (Jurnal Kajian Pendidikan Matematika), 2(1): 24 36. Diambil dari http://dx.doi.org/10.30998/jkpm.v2i1.1892.

Haryadi, R., \& Nurmaningsih. (2019). Analisis Kesalahan Mahasiswa dalam Menyelesaikan Soal

Persamaan Garis Lurus. Jurnal Elemen, 5(1): 1-11. Diambil dari http://ejournal.hamzanwadi.ac.id/index.php/jel. 
Mujib, A. (2017). Identifikasi Miskonsepsi Mahasiswa Menggunakan CRI pada Mata Kuliah Kalkulus II. Jurnal "Mosharafa", 6(2): 181-192. Diambil dari https://journal.institutpendidikan.ac.id/index.php/mosharafa/article/view/mv6n2_1.

Nasution, N. B. (2018). Analisis Kesalahan Mahasiswa pada Materi Fungsi Dua Peubah dengan Newmann's Error Analysis (NEA). SELTA Jurnal Ilmiah Pendidikan Matematika, 6(1): 2132. Diambil dari https://jurnal.unikal.ac.id/index.php/Delta/article/download/730/575.

Nur Afifah, D. S., Nafi'an, \& Putri. (2018). Analisis Kesalahan Mahasiswa dalam Menyelesaikan Soal Kalkulus Peubah Banyak. MaPan (Jurnal Matematika dan Pembelajaran), 6(2): $207-$ 220. Diambil dari https://doi.org/10.24252/mapan.2018v6n2a7.

Rahmawati, A. (2017). Analisis Kesalahan Mahasiswa Pendidikan Matematika dalam Menyelesaikan Soal Pertidaksamaan pada Mata Kuliah Kalkulus I. Al-Jabar: Jurnal Pendidikan Matematika, 8(1): 81-90. Diambil dari https://doi.org/10.24042/ajpm.v8i1.957

Seruni. (2018). Pengaruh Model Pembelajaran Terhadap Kemampuan Pemecahan Masalah. JKPM (Jurnal Kajian Pendidikan Matematika), 4(1): 35-42. Diambil dari http://dx.doi.org/10.30998/jkpm.v4i1.3060

Sulistyorini, Y. (2017). Analisis Kesalahan dan Scaffolding dalam Penyelesaian Persamaan Diferensial. Jurnal Pendidikan Matematika KALAMATIKA, 2(1): 91-104. Diambil dari http://dx.doi.org/10.22236/KALAMATIKA.vol2no1.2017pp91-104.

Wahyuni, A. (2017). Analisis Hambatan Belajar Mahasiswa pada Mata Kuliah Kalkulus Dasar. JNPM (Jurnal Nasional Pendidikan Matematika), 1(1): 10-23. Diambil dari http://jurnal.unswagati.ac.id/index.php/JNPM/article/viewFile/253/199. 